\title{
Off the Rails: Is State Ownership Bad for Productivity?
}

\author{
Dan Bogart* Latika Chaudhary ${ }^{\dagger}$
}

Draft: February 2015

\begin{abstract}
The performance of Indian railways in the nineteenth century provides a great context to study the effects of state ownership on productivity and other aspects of firm operations. We rely on a key feature of the institutional background whereby the colonial Government of India purchased a majority ownership stake in private railways at predetermined dates set by contracts negotiated decades before the companies came under state ownership. Controlling for individual railway fixed effects, year fixed effects, and railway-specific time trends, we find no evidence of a decline in TFP following state takeovers of private companies. Instead of reducing productivity, as the recent experiences with privatization would suggest, we find that the Government of India maintained productivity when it became the owner of railways. Government ownership influenced certain areas of operations such as the capital-labor ratio, but not others such as fares. Our results point to the conditions where state ownership is no worse than private ownership in terms of productivity.

Keywords: Nationalization, State Owned Enterprises, India, Railways, Institutions.

JEL codes: D2, H54, L33, N75, O2

*Associate Professor of Economics, UC Irvine, Email: dbogart@uci.edu

$\dagger$ Associate Professor of Economics, Graduate School of Business and Public Policy, Naval Postgraduate School, Email: lhartman@nps.edu

${ }^{\ddagger}$ We thank the Center for Global Peace and Conflict Studies (UC Irvine) and the Lowe Institute of Political Economy for funding. We also thank two anonymous referees and seminar participants at Yale University for comments. Latika Chaudhary was a Hoover National Fellow in Fall 2013 when part of this research was completed and thanks the Hoover Institution for support. Garrett Neiman, Shivani Pundir, Jennifer Ringoen, Nilopa Shah, and Sanjana Tandon provided able research assistance. The views expressed in this document are those of the authors and do not reflect the official policy or position of the Department of Defense or the U.S. Government.
\end{abstract}




\section{Introduction}

Economists and policymakers alike have long been interested in the costs and benefits of private versus state ownership. Although state ownership has been on the decline since the 1970s, large and important industries in many developing countries, especially Brazil, India, Russia, and China continue to remain under state ownership. In these and other countries where the state has a large ownership presence it is important to know whether there are any productivity losses from state ownership. The empirical literature on privatization argues that private ownership usually results in increased productivity suggesting that state ownership has efficiency costs (see surveys by Megginson and Netter 2001, Djankov and Murrell 2002, Guriev and Megginson 2007, and Estrin, Hanousek, Kočenda and Svejnar 2009). However, many studies focus on short panels comparing the three year pre-privatization performance to the three year post-privatization performance of the same firm. ${ }^{1}$ Such analyses miss the potential long run impact of an ownership change and are likely to confound the effects of privatization with other macroeconomic changes. Moreover, privatized firms are a selected sample and econometric analyses focusing only on these firms could significantly overstate the positive impact of privatization.

This paper uses the lens of history to better understand the effects of state and private ownership. Our historical setting - railways in colonial India - is especially suited to study this question for four reasons. First, there was a complete transition in the main trunk lines from private ownership to majority state ownership, which eliminates concerns about selection. Second, the timing of state takeovers was exogenous to firm performance because it was predetermined in contracts signed decades before the actual takeovers. As a result, the colonial state could not time takeovers to coincide with periods of increasing or decreasing productivity. Third, we have constructed a long panel of railways from 1874 to 1912 that allows us to distinguish between short and long run effects of state ownership. Fourth, we observe multiple railways being taken-over. By contrast most infrastructure settings study a single private or state firm undergoing an ownership transition.

The initial rail network in India was built and owned by British companies through the 1870s. The companies received a subsidy in the form of a $5 \%$ dividend guarantee to investors. A clause in the original contracts allowed the colonial Government of India to purchase railway companies only at specified future dates. Beginning in the 1870s, the Government

\footnotetext{
${ }^{1}$ Megginson, Nash and Randenborgh (1994) were the first to exploit such a before-after comparison of the same firm. This was a positive departure from earlier papers that relied on cross-sectional comparisons of private and state owned enterprises. See the summary tables in Guriev and Megginson (2007) for a list of papers that have used the MNR framework.
} 
began to exercise its purchase option and over the next three decades the Government of India took ownership of all the former private railways. By 1910 the Government owned over 70 percent of railway miles compared to less than 10 percent in 1875 . The general movement to nationalize railways in India was driven by political and fiscal considerations.

In this paper, we examine how state takeovers in India influenced a wide range of performance measures namely, total factor productivity or TFP, partial productivity in capital, fuel and labor, and other aspects of firm behavior such as investment, the capital-labor ratio, and average freight and passenger fares. Following the standard approach in the productivity literature, we measure TFP as a residual from a production function (Syverson 2011, Van Biesebroeck 2008) using passenger miles and ton miles as output. The inputs are labor, fuel, and capital. Our baseline specification controls for individual railway fixed effects, year fixed effects, and railway-specific time trends. Thus, we are identifying the effects of ownership by exploiting variation within railways over time.

Our empirical strategy addresses the possibility that railway companies could anticipate takeovers and respond accordingly. The main worry is that firms anticipating takeovers could run down investment and productivity in the years before takeover. Thus, TFP could be trending down in the years before takeover, which would generate a biased coefficient on state ownership. It seems the Government of India was also concerned about such anticipation effects because the original contracts specified that companies would receive the market value of their stock price averaged over the three years before takeover. To test for anticipation effects by private companies, we interact state ownership with an indicator variable for the 3-year window before takeover. We also test for differential short and long run effects by interacting state ownership with an indicator variable for the first three years after takeover including the year of takeover, and for 3 or more years after takeover.

The empirical results yield a clear conclusion: state ownership had a negligible impact on the TFP of Indian railways. Our period of study was one of high productivity growth in railways. Even after state takeovers, railways did not deviate from this general trend of high productivity growth. In specifications that control for anticipation effects, we find no significant decline in TFP in the years before takeover and the main effect on state ownership is unchanged. There are also no significant differences in the impact of state ownership between the short run (first 3 years after takeover) and the long run (3 or more years after). Moreover, the results on partial productivity and fares find no evidence of a negative impact of state ownership.

Interestingly, we find capital intensity (i.e., capital to labor ratio) increased following state takeovers. This possibily relates to the Government reducing or eliminating dividend 
guarantees under state ownership. While the guarantees arguably encouraged capital investment in the early phase of Indian railway development, by the late nineteenth century they clearly raised the cost of capital because of declines in the interest rate and hence the Government's cost of borrowing. Unlike contemporary settings, the colonial Government also did not expand employment after takeover, another factor contributing to higher capital-labor ratios.

Overall, the findings relate to a growing literature on the organization and efficiency of Indian railways. Historians have written extensively about regulation and ownership mostly focusing on whether dividend guarantees to private railways was a useful policy. ${ }^{2}$ We have contributed to this literature in our previous work. In Bogart and Chaudhary (2012) we find that variable costs declined following the switch to state ownership without an increase in the number of accidents. In Bogart and Chaudhary (2013) we estimate the aggregate performance of Indian railways and find high TFP growth rates relative to other sectors of the Indian economy and railways in other parts of the world.

In this paper, we return to the question of state ownership using newly constructed railway-level series on capital and fuel inputs along with freight and passenger fares. By expanding our scope to capital and related measures of total and partial productivity, this paper offers a comprehensive study of the effects of state ownership on the performance of Indian railways. Unlike the findings on variable costs (Bogart and Chaudhary 2012), we find no positive effects of Government ownership on total factor productivity or fares. We find positive effects of state ownership on capital intensity, but interestingly the more capital intensive railway systems did not translate into productivity gains. The overall picture suggests the Government takeover of Indian railways had a neutral effect on performance.

Our findings are different from many empirical studies in the privatization literature. A recent survey by Guriev and Megginson (2007) suggests average productivity improves by 20 percent following privatization. ${ }^{3}$ However, in our case a 95 percent confidence interval for the long run effect of state ownership on TFP ranges from negative 7 percent to positive 8 percent. It is far from a 20 percent decline in productivity that would be predicted by many privatization studies.

Although different from much of the literature, we are not the first to find negligible or mixed effects from state ownership. For example, Kole and Mulherin (1997) find no difference in performance of US firms that came to be government-owned during World War II. Feng, Sun and Tong (2004) find no difference in income and efficiency between government-linked

\footnotetext{
${ }^{2}$ See Sanyal 1930, Thorner 1977, Kerr 2007, Sweeney 2011, Hurd and Kerr 2012 among others.

${ }^{3}$ For similar estimates of privatization see Jones and Mygind (2002), La Porta and Lopez-de-Silanes (1999), Claessens and Djankov (2002).
} 
companies and a matched sample of non-government-linked companies in Singapore. Studies of firms in China (Sun and Tong, 2003) and Spain (Villalonga, 2000) also fail to find large positive effects of privatization. Using a large panel of Eastern European firms, Brown, Earle and Telegdy (2006) find an increase in TFP after private takeovers in Romania and Hungary, but no effect of private takeovers on TFP in Ukraine, and a negative effect in Russia.

In the railway sector the link between ownership and productivity is also mixed. A classic study by Caves and Christensen (1980) finds no difference in the productivity performance between the state owned Canadian National and privately owned Canadian Pacific. However, Laurin and Bozec (2001) find that the Canadian National's productivity rose faster just prior to and after its privatization in 1995. Estache, González, Trujillo (2002) find similar positive effects for productivity following the recent privatization of railways in Brazil and Argentina. Using historical cross-county data, Bogart (2010) finds that railway nationalizations are associated with lower cost efficiency but the manner of nationalization is also important. Efficiency is lower when the state takes over private railways compared to when the state constructs national railways.

This naturally leads to the question: when is state ownership harmful for productivity and when is it no worse than private ownership? The Indian case suggests three relevant factors. First, a private sector operating under rate of return guarantees is more likely to produce comparable productivity to firms in the public sector. In the case of Indian railways, guarantees weakened incentives to improve peformance and over time they lead to biases in the cost of capital. Second, productivity under state ownership is likely to be more similar to private ownership if the government is undemocratic. The famous economist Alfred Marshall quoted a saying in the early 1900s, which argued that "under a democratic constitution, state railways corrupt politics and politics corrupt state railways (p. 496)." The Indian case supports this assertion. In India the undemocratic colonial state was not beholden to public sector labor unions or local politicians. The British administrators that ran India had little incentive to use railways as a tool to buy votes - say by providing jobs or building a station in every town.Third, productivity under state ownership is likely to be similar to private ownership whenever the performance of the enterprise is of great value to the government. In colonial India, government owned railways were a key contributor to gross government revenues - 35 percent by 1913. The colonial government had a weak fiscal system and thus could not easily generate the same revenues from other sectors. Railways also provided key logistical support in defending the empire. Britain's control over India would have been more tenuous had it not been able to quickly move troops to various 
frontiers.

The rest of the paper is organized as follows. Section 2 describes the relevant institutional details followed by how the theoretical literature on ownership applies to the Indian context in section 3. We describe our data in section 4 and empirical strategy in section 5 . The results are presented in section 6 followed by conclusions in section 7 .

\section{Background on Indian Railways}

The main Indian trunk lines were constructed in the 1850s and 1860s by British railway companies. Ten such companies incorporated in Britain entered into contracts with the Secretary of State, a British Cabinet member with formal control over the administration of India. Two of the original companies merged leaving 8 such companies by 1870 . Figure 1 depicts the railway companies operating in India in 1870 and their routes. The oldest and largest of these companies were the East Indian and the Great Indian Peninsula Railways connecting the ports of Calcutta and Bombay respectively to the interior of the country. Sind, later renamed the Sind, Punjab, and Delhi Railway company also had a large network in the northwest connecting the port of Karachi. Connecting the main ports to the interior and to each other was an important goal of colonial rail policy in keeping with Britain's military, political and trade interests in India.

These private British companies were joint stock companies and their contracts with the Secretary of State shared common features. Land was provided free of cost by the Government of India. The companies raised capital in Britain via shares and received a 5 percent guarantee on the share capital at a fixed exchange rate. The net earnings from railway operations were paid into the Government treasury and rebated to the companies. If net earnings as a proportion of capital outlay fell short of the guaranteed 5 percent, the Government made up the difference up to 5 percent. However, such guarantee payments were treated as debt. If annual returns exceeded 5 percent, the Government received half of all surplus profits above the guarantee and shareholders received the other half. Once past guarantee payments were paid off, company shareholders received all the profits. ${ }^{4}$

In exchange for the guarantees, the Government retained control over certain aspects of the railways. The Government had ultimate authority on route placement and gauge. They could also influence operations through a government director who sat on the company boards. Finally, the Government could purchase private railways on the $25^{\text {th }}$ or $50^{\text {th }}$ anniversary of their original contract with the mean market value of the company's stock

\footnotetext{
${ }^{4}$ See Sanyal (1930) for details.
} 
in the preceding three years determining the purchase price (Bell 1894, p. 66-72). This is a key contractual feature from an identification perspective because the Government could not time takeovers depending on company performance.

India's experience with railway guarantees was mixed. While such contracts allowed British capital to finance Indian railway construction, many of the companies were unable to generate returns over 5 percent in the $1850 \mathrm{~s}$ and $1860 \mathrm{~s}$. Hence, the Government and Indian taxpayers made up the difference to British shareholders via guarantee payments totaling almost 30 million pounds by 1869 (Hurd 1983). To put this in perspective, the Government paid 1.72 million pounds in guarantees in 1869 which represented $20 \%$ of its total spending on public works (Great Britain 1878). The Government also incurred losses on account of the fixed exchange rate stipulated in the contracts. In the 1860 s and $70 \mathrm{~s}$, the rupee was worth no more than $1 \mathrm{~s}$. $8 \mathrm{~d}$ while the contract rate for guarantee payments was 1s. $10 \mathrm{~d}$ to the rupee. The devaluation amounted to approximately a $10 \%$ increase in real payments collected by companies.

On account of the disappointing performance of the guaranteed railways, the Government decided to construct and manage state owned railways in the 1870 s. The Government borrowed money on London capital markets in the form of Government of India bonds to finance these projects. It was spurred by the lower cost of public borrowing. From 1860 to 1873 the yield on Government bonds averaged 4.6\%, not much below the guarantees of 5\%. In the next 10 years from 1874 to 1883 the yield averaged 3.7\%. This period of extensive state construction largely ended in the early 1880s. The economic depression in the $1870 \mathrm{~s}$ coupled with the war in Afghanistan crowded out government spending on railways.

The question of whether guaranteed companies should be allowed to retain ownership of the main trunk lines came to the forefront in the late 1870s with the approaching $25^{\text {th }}$ year anniversary of the East Indian railway in 1879. Years of guarantee payments and a perception of poor performance turned many officials against the model of full private ownership with guarantees (Sanyal 1930, Sweeney 2011). In 1877, the Secretary sent a letter to the East Indian railway company directors indicating the Government's intention to purchase the line but suggested a new arrangement whereby the company would operate the railway in exchange for a portion of the profits and a reduced guarantee (Huddleston, 1906 p. 101). Thus, the East Indian railway came under Government ownership in 1880 worked by the newly formed East Indian company, which retained one-fifth of the capital, now guaranteed at 4 percent, and also received one fifth of surplus profits for working the lines.

Over the 1880s, 1890s, and 1900s, the Government purchased all the original guaranteed 
companies. Most of them were taken over on the $25^{\text {th }}$ year of their original contract, with the exception of the Great Indian Peninsula, Bombay, Baroda and Central India, and the Madras railway. These three were taken over on their $50^{\text {th }}$ contract anniversary because of a negotiated deal in 1869 with the Secretary of State in which their past guarantee debt payments up to that year were forgiven in exchange for sharing surplus profits above 5 percent with the Government from that year forward. The Secretary also agreed to not takeover these railways on their $25^{\text {th }}$ anniversary. ${ }^{5}$

Following takeovers, the Government implemented one of two operational models. In three cases, the Government chose to operate railways after takeovers. ${ }^{6}$ In the five other cases, the Government entered into agreements with directors of the former railway companies. The newly formed companies generally held less than 20 percent of the capital. The profits were guaranteed, at lower rates of 3 to 4 percent and at smaller capital values. Surplus profits were shared with the Government in proportion to their respective capital shares.

To address the need for new railways, the Government relied on a public-private partnership model similar to the one negotiated with the guaranteed companies upon takeover. Beginning in the mid-1880s, the Government entered into contracts with new private companies whereby the state owned the railway but the company constructed and managed the lines in exchange for a small portion of the surplus profits. The Government also supported a few privately owned railways in the 1880 s with state subsidies. Finally, a few Princely States constructed and managed their own railways. ${ }^{7}$ Such railways (under Government ownership, Princely State ownership or private ownership) constructed after the 1870s did not experience any change in ownership.

The transition to state ownership between 1874 and 1912 was the key first step in India's move to complete nationalization of its railways. ${ }^{8}$ Our empirical analysis exploits Govern-

\footnotetext{
${ }^{5}$ This deal was offered only to the four biggest railways, these three plus the East Indian. However, the East Indian refused the offer because it was a profitable company and its past debts on account of the guarantee were small compared to the others. We believe railway fixed effects capture the differences in size and any other time invariant factors that lead to these companies being taken over on their $50^{\text {th }}$ anniversary.

${ }^{6}$ We do not study operations in detail because different reasons appear to have driven the operation decision such as military concerns in one case versus private mis-management in another case. This potential endogeneity combined with fewer operational switches in the data make it difficult to accurately identify the effects of operation. Instead our focus is on the transition to majority Government ownership which was common among all guaranteed railways.

${ }^{7}$ The Princely States represent a large number of semi-autonomous kingdoms ruled by native Indian rulers in contrast to British India that was under direct colonial authority. In exchange for local autonomy, the Princely States deferred to the British on matters of defense and foreign affairs.

${ }^{8}$ There was another important change beginning in the $1920 \mathrm{~s}$, when public opinion turned against private operation and the Government gradually took over railway operations in the 1930s and 1940s.
} 
ment of India takeovers of guaranteed companies to identify the effects of state ownership on productivity. In addition to the treatment group, the Indian context offers a control group because many railways did not experience a change in ownership. While it has many advantages from a research design perspective, the Indian context presents two challenges that we address. First, the Government pushed a few mergers in the years immediately following takeovers. For example, the private Sind, Punjab and Delhi Railway was merged with the state owned Indus Valley and Punjab Northern lines upon takeover among other mergers. To separate the confounding effects of mergers from takeovers, we construct a special 'joint' panel of railways described in the data section. Second, the timing of government takeovers was different for railways who struck a deal with the Secretary of State in 1869. Hence we test for differential effects between the late takeovers in the 1900s and the first wave in the 1880 s.

Transitioning to Government ownership was a significant change because it increased the Government's control and supervision of railways. Huddleston's (1906) history of the East Indian railway discusses how directors had greater autonomy in developing the East Indian's network, in setting fares, and managing the stock of wagons prior to 1879 when it was taken-over. Afterward, there were several controversial decisions in which the directors had to acquiesce to Government demands on these issues. More generally, ownership had the potential to influence many dimensions of productivity. For example, private company directors or state officials in the Indian Civil Service made purchasing decisions about the models of locomotives, wagons, and coaches, which likely influenced productivity. Directors and officials decided whether to adopt expensive new technologies such as inter-locking signaling systems and air vacuum brakes that improved safety. Owners designed compensation packages for their employees. At the time, it was common for both private and state owned railways to have a pension fund, in which employees and railways made joint contributions. Perhaps the most important decision concerned the scale and design of the railway network. A railway system that runs trains more frequently over its network will be more productive. Such economies of density may also depend on ownership.

To the extent that ownership changed control rights, it could thus impact the productivity and efficiency of Indian railways. In the period we study, 1874 to 1912, Indian railways witnessed tremendous productivity growth, averaging 2.3 percent per year. As we show elsewhere, the aggregate productivity gains were not driven by reallocation within the railway sector. Rather all Indian railways systems moved closer to the technology frontier in the early twentieth century (Bogart and Chaudhary 2013). In the next section, we discuss the theoretical literature on ownership and firm performance examining the implications for the 
Indian case.

\section{Theory and its Application to Indian Railways}

A vast theoretical literature in economics has studied the relationship between ownership and performance with researchers making arguments both for and against state ownership. In a classic paper, Sappington and Stiglitz (1987) highlight the differential ability of the government to intervene in the production activities of private and public firms. In this vein, researchers have argued that state ownership reduces performance because governments generally cannot commit and thus they appropriate the surpluses associated with managerial investments. The hold-up problem, as it is known, is one key reason why mangers in private firms have stronger incentives to cut costs and improve efficiency (Hart, Shleifer, and Vishny 1997, Shleifer 1998). A different theoretical argument in favor of private ownership suggests that state owned firms may promote political objectives over profit maximization. For example, they may pursue schemes of greater employment or universal coverage of service that are not necessarily efficient (Boyko, Shleifer, and Vishny 1996).

Some examples from the historical record raise doubts about these views in the Indian case. Anecdotal evidence suggests the Government of India took an active interest in the management of railways once they were state owned. For example, repairs to locomotives and carriages were centralized in the Lahore workshop following the merger and reorganization of the Sind, Punjab, and Delhi Railway company with the Indus Valley and Punjab Northern state lines in 1886. Concentrating the repair process in a single location contributed to the use of more sophisticated technology and avoided the redundancy of having three individual workshops in the region (Kerr 2007, p. 85). In another example Indian farmers and merchants made requests to extend the network of the East Indian railway when it was under state ownership into less populated regions and to expand its wagon stock to handle exceptional periods of freight. The Government of India refused these requests because they were considered uneconomical (Huddleston 1906). It could safely make such choices because there were fewer political consequences from ignoring constituent demands for an authoritarian government.

The Government also stood to benefit from a well functioning railway sector because of its heavy fiscal reliance on railways. Almost 35 percent of Government gross revenues came from state owned railways by 1912 (Great Britian 1922). In 1909 it was reported that the net profits from railways were enough to meet all outstanding interest payments on Government of India debt (Sweeney 2011, p. 170). The Government's dependence on railway revenues 
was due to a weak tax system. Per capita taxes in British India were only 5 to 8 percent of those in Britain (Roy 2011). The Government relied heavily on land taxes but was unable to increase rates to capture changes in productivity and landed wealth. According to Roy (2011), land taxes as a share of agricultural production declined from 10 percent in the 1850s to under 5 percent in the 1930s (p. 256). Indian opposition to taxes made it difficult for the colonial state to tap into new sources of tax revenue especially in the twentieth century and the tax to GDP ratio continued to remain low up to independence. While this weak fiscal system was undesirable from a development perspective, it may have provided a mitigating factor for railway productivity. ${ }^{9}$

A different theoretical literature on regulation of utilities points to channels by which private ownership can fail to achieve better firm performance. In practice subsidies or guarantees to private companies are common in the infrastructure sector. ${ }^{10}$ They have been studied in the theoretical literature especially when private firms require insurance against downside demand risk, but their efforts in reducing costs are not readily observed. ${ }^{11}$ In such contexts, Engel, Fischer and Galetovic $(2009$, 2010) show that the optimal procurement contract contains minimum revenue guarantees to mitigate risk, but they should not be too generous as to induce sub-optimal cost-reducing effort.

The Indian case suggests the 5 percent dividend guarantee was perhaps too generous and likely dulled company incentives to manage costs judiciously. Contemporaries often criticized the guarantee system exactly for this reason. Horace Bell in his history of Indian railways disapprovingly noted that "shareholders had their 5 percent whatever happened (Bell 1894, p. 66)." The Secretary of State in 1868 advocated the use of guarantees, but admitted, "the system tends to weaken the ordinary motives to efficient management and superintendence (Bell 1894, p. 19)." A good example of wasteful spending is the East India Company's procurement of sleeper cars. Before its government takeover, it spent 52,000 pounds on iron sleepers when creosoted timber sleepers were likely to be just as durable and cost about half as much (Sweeney 2011, p. 26).

Guarantees also have implications for capital investment and the scale of railway systems. As noted above the Government of India's cost of borrowing was around $4.6 \%$ in the 1850 s and 1860s when the guarantee contracts were signed. However, by the mid 1870 s the Government of India's cost of borrowing was under $4 \%$ and by the 1880 s it was under $3.5 \%$.

\footnotetext{
${ }^{9}$ In theory, if the Government valued the public good benefits of railways more than other actors, then its ownership could be considered optimal according to the property rights model developed by Besley and Ghatak (2001).

${ }^{10}$ Guarantees to private companies were commonly offered during the historical era of railway construction (Eichengreen 1995).

${ }^{11}$ See Martimort (2006), Auriol and Picard (2009), Estache and Wren-Lewis (2009).
} 
It no longer made sense to guarantee railways a $5 \%$ return when the return on capital in India had fallen to less than $3.5 \%$. The problem was magnified by the requirement that guarantee payments must be made at the exchange rate of the 1850 s, even though the Indian Rupee had depreciated relative to the pound sterling by the 1870s. The Government of India perhaps responded by limiting the capital investments of guaranteed railways. One potential mechanism was to restrict the network expansion of existing guaranteed railways and build new state owned lines. A good example is the Indian Midland railway which was built at the edges of the Great Indian Peninsula railway's network when it was still private. The Indian Midland railway company operated the line at a guarantee of $4 \%$. If the Great Indian Peninsula would have built the line the Government would have had to pay its usual guarantee of $5 \%$.

To summarize, the standard models, which assume that state owned firms do not maximize profits or have weaker incentives than private companies, do not appear to be a good description of Indian railways. Similar to other contexts, we believe the question of whether state ownership influenced the productivity of Indian railways is an empirical one and we use detailed data from this period to answer the question.

\section{Data}

Our dataset builds on earlier work (Bogart and Chaudhary 2013), which constructed new consistent series on output, labor, capital and fuel for the major standard and meter gauge railways operating in India between 1874 and 1912. ${ }^{12}$ The sources for the data include the annual Report to the Secretary of State for India in Council on Railways in India, published from 1860 to 1883 and the Administration Reports on the Railways in India, published from 1884 to 1912. These series report information on passenger miles, tons miles, fuel, labor, the value of capital, fares and the ownership structure of each railway. We begin by describing our unit of analysis followed by the construction of the main variables used in the regressions.

Our analysis follows a railway or railway system, which includes the main line accounting for more than 90 percent of the mileage on average and any secondary lines operated by the system that are owned either by the Government of India, private companies or Princely

\footnotetext{
${ }^{12}$ We begin the analysis in 1874 when the official documents begin reporting consistent output and input data. As is the common in the transportation literature, our measure of output is a weighted average of passenger miles (number of passengers carried 1 mile) and ton miles with cost elasticities serving as the weights. We direct the interested reader to Bogart and Chaudhary (2013) that describes in detail how we constructed the output and input series.In that paper we used individual-railway data to estimate the aggregate performance of Indian railways and compared it to other sectors of the Indian economy.
} 
States. ${ }^{13}$ Ideally, we would like to follow this railway system for the entire time period but mergers between lines complicate the process. To address the issue of mergers, we follow a railway system and include information on the pre-merged lines to each system before they are officially merged together. ${ }^{14}$ We call this our 'joint' panel of railways. By following a consistent joint panel of 20 railway systems, mergers are less likely to confound our results on state ownership. As a robustness check, we also follow a 'solo' panel of railways where each system enters as a separate observation even if it goes on to merge to another system in future years.

We use information from the Reports on the timing of state takeovers to construct an indicator variable for state ownership, which switches to one in the first year the state becomes the majority owner of the main railway and remains one for the rest of the time period. The main lines on average represent the majority of total mileage but our railway systems also include a small mileage of lines that may be under different ownership from the main line. As a robustness check, we also construct the fraction of miles within a system that are state owned.

We focus on two measures of total factor productivity (TFP). Our first TFP measure is the commonly used Index Number approach where TFP is the difference between output growth and a weighted average of the growth of the inputs namely capital, labor and fuel. The weights are the share of total costs paid to each input. We do not observe these cost shares but the Reports suggest working costs accounted for 45 percent of total revenues on average from 1882 to 1912, implying 55 percent of revenues were paid to capital. We rely on evidence from the East Indian railway to determine the split between labor and fuel where labor costs were two-thirds of working expenses (Derbyshire 1987). This implies a capital cost share of 0.55 , labor 0.3 , and fuel 0.15 . These shares are in line with historical studies on railway productivity. ${ }^{15}$

The Index Number method assumes constant returns to scale and perfect competition that are perhaps problematic in the railway context because many railways could operate as

\footnotetext{
${ }^{13}$ For example, the East Indian railway system operated the primary East Indian line owned by the East Indian railway company up to 1879 and the Government from 1880 onwards, three state-owned lines, and by 1912 three lines owned by other companies. For railways that manage multiple lines, the railway system is the most consistent unit we can follow because the data are reported for the system. When the railway does not operate secondary lines, the unit of analysis is the railway.

${ }^{14}$ The only exceptions are the break up of East Coast State railways in 1900 and the re-organization of Madras, Southern Mahratta and South Indian railways in 1908. East Coast railway began operations in 1895. In 1900, part of the railway was merged with Madras and another section was merged with Bengal Nagpur making it difficult to accurately assign the pre-merger information.

${ }^{15}$ For example, Crafts, Mills, and Mulatu (2007) assume a 0.63 share for capital, 0.34 for labor, and 0.03 for fuel on British railways. Fishlow (1966) assumes shares of 0.52, 0.38, and 0.1 for capital, labor, and fuel respectively on U.S. railroads.
} 
monopolies in their geographic location and exhibit scale economies. Hence, we also use TFP estimates derived from regression analysis. The main concern in parametric estimations of TFP is generating unbiased estimates of input elasticities. If input choices are correlated with unobserved productivity shocks i.e., simultaneity problem, then the coefficients on the input elasticities are biased. For example, firms with positive productivity shocks may use more inputs making it difficult to separate the effects of inputs from productivity shocks.

One solution is the Levinsohn and Petrin (2003) estimator, which uses intermediate inputs such as fuel, materials and electricity to address the simultaneity problem. ${ }^{16}$ The key assumption underlying the LP method is that of monotonicity. ${ }^{17}$ More productive firms should produce more output using more of the intermediate input, fuel in our case, conditional on capital. We believe this is a reasonable assumption even though Indian railways were not a perfectly competitive industry. The main reason more productive firms would use less fuel would be if they had access to more fuel-efficient technology not captured in capital. Based on our reading, it is not clear which type of railway technology would achieve lower fuel outside of new locomotives or wagons which are included in capital. More generally in railways it is hard to imagine carrying more passengers and freight without running more trains and using more fuel. The LP method also assumes capital is a function of investment decisions made in earlier periods and hence is uncorrelated with unobserved productivity shocks in the current period. Again, this is a reasonable assumption in our context because railway capital clearly evolved from investment decisions made in past years.

Using the LP method, we first estimate the coefficients on capital, fuel and labor. ${ }^{18}$ Then we calculate the log of individual railway TFP as follows:

$$
t f p_{i t}=y_{i t}-\left(\widehat{\alpha}_{0}+\widehat{\alpha}_{l} l_{i t}+\widehat{\alpha}_{k} k_{i t}+\widehat{\alpha}_{m} m_{i t}\right)
$$

where $\widehat{\alpha}$ 's are the estimated parameters. In addition to these two measures of TFP, we study the effects of state ownership on partial productivity measures namely capital, fuel and labor productivity, investment, the capital-labor ratio and average passenger and freight fares (the sum received for carrying one passenger one mile or one ton of goods one mile). ${ }^{19}$

Table 1A reports summary statistics for the main variables in the joint panel. TFP is

\footnotetext{
${ }^{16}$ Other solutions proposed to this problem such as in Blundell and Bond (2000) are not suitable for our context of small $\mathrm{N}$ and large $\mathrm{T}$.

${ }^{17}$ In the LP framework, the intermediate input, fuel in our case, is expressed as a function of capital and the endogenous portion of the error term (the unobserved productivity shock correlated with input choices). Assuming monoticity allows an inversion of the demand function for fuel whereby the endogeneous error term is now expressed as a function of fuel and capital.

${ }^{18}$ In Bogart and Chaudhary (2013), we find large and positive correlations between different methods of estimating railway-level TFP such as the LP, IN and FE.

${ }^{19}$ The data on fares are reported from 1880-1912.
} 
the most important and it increased rapidly for most railways. To illustrate the trend figure 2 shows an index of the output-weighted average of railway TFP in each year beginning in 1874. Industry TFP was very volatile in the late 1870s on account of the severe famines in 1877 highlighting how macro events influenced railways. Average TFP growth changes from being stagnant in the 1890s to accelerating at a very fast pace in the 1900s. While these productivity gains were evident for most railways, there were important differences in levels across railways as reflected by the standard deviation.

Another important variable is the indicator for state ownership. Figure 3 shows the fraction of total railway miles in our sample by ownership. While guaranteed companies accounted for most of the total mileage in the 1870 s at over 90 percent in 1874, their share declined to 0 by 1908 when the last guaranteed company (Madras Railway company) was taken over. As private guaranteed mileage decreased, there was a parallel increase in Government of India owned mileage from less than 10 percent in 1874 to over 70 percent by 1912. The remaining miles were owned by a small number of second generation private assisted companies formed in the 1880s and 1890s accounting for less than 10 percent by 1912. Finally, the Princely State owned railways accounted for just over 10 percent of the mileage by 1912 .

In table $1 \mathrm{~B}$ we present the summary statistics of the main variables separately for switching and non-switching railways. There are no significant differences in TFP, capital and fuel productivity between the two types of railways. Switching railways are bigger in size (investment), which stems from mergers after takeover as described above. They also have higher labor productivity than non-switching railways that were mostly under state ownership for the entire time period. Again, this difference is not too surprising. If we focus only on the pre-treatment period, switching railways have higher labor productivity and capital-labor ratios. But, there are no significant differences in TFP, capital productivity and fuel productivity. We find it reassuring that the TFP is similar across the two groups in the pre-treatment period, which suggests TFP changes in the non-switching railways provide a decent counter factual for switching railways. In the next section we describe our methodology, which moves beyond cross-sectional comparisons to changes within the same railway company.

\section{Empirical Framework}

Much of the recent literature on ownership and firm performance has studied the transition to private ownership because many countries have moved away from state owned enterprises 
to private firms in the last four decades. These studies of privatization encompass firms in post Communist transition economies (review by Estrin et. al. 2009), in Latin American countries (Anuatti-Neto et al. 2004, Galiani et al. 2004) and even in China where state firms have adopted elements of private ownership (Li 1997, Dong, Putterman and Unel 2006).

The early works in this literature were cross-sectional comparisons between private and state owned firms controlling for other factors influencing productivity and ownership. For example, Boardman and Vining (1989) compared the performance of state owned enterprises to private firms across 500 large non-industrial firms with operations outside the United States in 1983. Using a single cross-section of firms to identify the effects of ownership structure is problematic because of omitted variables. Private firms are not randomly assigned and differ from state owned firms. Hence it is difficult to disentangle the effect of ownership from other variables that systematically vary by ownership.

An important step forward was seminal work by Megginson, Netter, and Randenborgh (1994) that compared the pre and post privatization performance of a sample of 61 firms across many countries and industries. They estimated pre-privatization means averaged over three years before an ownership change for return on sales, net income efficiency and capital expenditure among other measures. They compared this mean to the post-privatization mean again averaged over three years after privatization.

Comparing the before and after performance of the same firm was a major advance over across firm comparisons. But, two issues still remained. One, the short before and after time period may be insufficient to identify changes in firm performance that develop after three years. For example, Megginson, Netter and Randenborgh find privatization does not increase unemployment. However, it is possible recently privatized firms need a few years to identify which set of employees to lay off. More importantly, there may be other changes in the macro-economy apart from privatization, which would confound causal estimates of privatization. For example, privatization in Central and Eastern Europe was accompanied by an increase in international trade, improvements in market institutions, and other macro reforms (Estrin et al. 2009).

The natural step forward has been a difference-in-difference research design where the before-after performance of treatment firms is compared to the before-after performance of control firms that do not experience ownership changes in the same period. We believe Brown, Earle and Telegdy (2006) have set the 'gold standard' in executing such an analysis. Using detailed data on manufacturing firms in Hungary, Romania, Russia and Ukraine from 1985 to 2002, the authors compare multifactor productivity before and after privatization within firms relative to before-after changes in firms that do not experience privatization. 
Unlike other studies, they exploit a longer panel of firms to identify the effects of privatization. Borrowing from labor econometrics techniques, they are also the first in this literature to account for firm-specific trends and model anticipation effects whereby treatment firms respond differentially in the pre-treatment period. Our paper uses similar techniques to estimate the effect of state ownership in the context of Indian railways.

We begin by implementing a simple reduced form framework shown below.

$$
y_{i t}=\alpha+\beta \text { StateOwnership } i t+\delta_{i}+\gamma_{t}+\lambda_{i} Y \text { ear }+\varepsilon_{i t}
$$

Here $y_{i t}$ captures railway level outcomes such as TFP (IN or LP), partial input productivity, investment, the capital-labor ratio and fares. StateOwner ship is a dummy for when private railways came under Government of India ownership. Our panel of railways includes both switchers and non-switchers that remain state owned or native state owned throughout the period of study. In our joint panel we are comparing the average change in performance for 8 switchers relative to 12 non-switchers. We also include a robust set of fixed effects. We exploit within railway variation by including railway fixed effects, $\delta_{i}$. We control for annual macro-economic or other temporal shocks that may influence railways in the same manner by including year fixed effects, $\gamma_{t}$.

Following Brown, Earle and Telegdy (2006), we include interaction terms between a time trend and an indicator for each railway, $\lambda_{i} Y e a r$, to control for unobservable trends at the railway level. If a railway that was to be purchased by the Government was on a different trend from a non-switching railway, then the estimated coefficients would be biased. Controlling for railway specific trends alleviates such concerns. It allows us to identify the effects of state ownership by comparing deviations in TFP from the railway trend before and after the change to state ownership within a railway system. Lastly, the standard errors are clustered at the railway level to address potential serial correlation in the data. ${ }^{20}$

Our institutional background offers two key advantages vis-à-vis identifying the effects of ownership. First, the state took over all the original private guaranteed companies, which reduces selection concerns that the state was taking over only the most profitable companies. Second, the Government could not time the takeovers to periods of low or high productivity because the takeover dates were determined decades in advance. The Government could only takeover firms on the $25^{\text {th }}$ or $50^{\text {th }}$ anniversary of their original contracts. Although this

\footnotetext{
${ }^{20}$ In our context, we have 20 clusters that may be too small to generate reliable clustered standard errors. The main concern with few clusters is that the clustered standard errors may be biased down and studies are more likely to reject the null when in fact it is true (i.e., Type 1 errors). In a robustness check, we estimate p-values with wild bootstrap as suggested by Cameron, Gelbach and Miller (2008) to address the problem of few clusters. Our findings are essentially the same so we report the clustered standard errors throughout.
} 
suggests the state could not endogenously time takeovers, it raises concerns that private firms may have anticipated and reacted in advance to state takeovers.

To investigate such anticipation effects, we estimate the dynamics of state ownership by interacting a dummy for state ownership with a three-year bin before takeover. We focus on the three year window because the price at takeover was determined by the average stock price of the railway over the three years before takeover. Private railways were taken over in different years during our period of study and so we observe them for a different number of pre and post years. Fortunately, we observe all the railways for three years pre and post takeover, which ensures we are studying a balanced panel during those windows. We also investigate differences between the short and long run dynamics of state takeovers by interacting state ownership with a three year window after takeover including the year of takeover plus one and two years after takeover (short run effect), and with years three and beyond after takeover (long run effect).

\section{Results}

\subsection{TFP and Partial Productivity}

Table 2A presents our first set of results on the relationship between state ownership and productivity in the long run. Panel A captures the change in ownership with a simple dummy variable for when majority of the mileage came under Government ownership. We find no significant long run negative effect of state ownership on either measure of total factor productivity. The coefficient on state ownership in the case of TFP-LP is very close to zero: a positive and insignificant effect of 0.4 percent following state takeovers. Since the Levinsohn-Petrin TFP estimate addresses potential endogeneity of input choices, we prefer LP to the Index Number estimate. That said, we present results on both TFP measures to highlight that our findings are similar regardless of the metric used. In the case of TFP-IN, the coefficient on state ownership suggests a negative effect of -2.4 percent, but is statistically insignificant.

Apart from TFP, we also study partial productivity in table 2A. Mirroring the TFP results, we find no significant effects of state ownership on labor, capital or fuel productivity. The coefficient on state ownership is positive but insignificant for labor productivity (this is contrary to the findings of many privatization studies as we discuss below). The coefficient on fuel productivity is small and insignificant, while that on capital is negative but insignificant. Panel B uses the fraction of state owned miles to measure the switch in ownership and essentially finds the same results. An increase in the fraction of state owned miles has no 
significant negative effect on either TFP or partial productivity of labor, capital and fuel. ${ }^{21}$

Since state takeovers in a few cases were immediately followed by important railway mergers, we prefer the joint panel because it maintains a constant unit of analysis and therefore separates the effects of state ownership from mergers. But, as a robustness check we replicate the analysis from table $2 \mathrm{~A}$ on the solo panel of railway systems. These results are presented in table $2 \mathrm{~B}$. The coefficients on state ownership are slightly larger but never significant, and confirm our main findings of no negative effects of state ownership on productivity. We have subjected the findings to many robustness checks such as weighted regressions and alternate estimates of TFP, but state ownership never has a significant negative effect on productivity. ${ }^{22}$

Although tables $2 \mathrm{~A}$ and $2 \mathrm{~B}$ establish state ownership of Indian railways did not reduce productivity on average following takeovers, the exercise does not reveal anything about the short and long run dynamics. Such dynamics are relevant for two reasons. First, it is possible state ownership has differential effects on productivity depending on the time horizon. If a state struggles to manage newly acquired enterprises in the short run, productivity may be negative in the years immediately following a takeover. But, if a state overcomes these challenges, productivity may return to or even exceed pre takeover levels in the long run. These two effects could offset each other leading to an insignificant average effect. One could also imagine the opposite scenario.

Second and more importantly, firms can anticipate ownership changes and react to them before a takeover. The Government of India could not time takeovers but companies could anticipate the takeover and respond in the preceding years. Anticipation effects complicate the interpretation of state ownership. If firms begin responding to a potential takeover 2 to 3 years prior to the actual takeover, then we may want to compare the TFP under state ownership to TFP some years prior to takeover.

To test for dynamics, figure 4 plots the coefficients on state ownership interacted with -3, $-2,-1$ years before takeover and 1, 2, 3, and up to 10 years after takeover. These coefficients are from a regression on TFP-LP in the joint panel including railway FE, year FE and railway specific trends. Although we show estimates for 10 years after takeover, we believe the three year before and after window is the easiest to interpret because we observe all the switching railways in this window and our panel is balanced. The coefficients are all

\footnotetext{
${ }^{21}$ Since we find statistically insignificant effects of state ownership, we are less concerned about Type 1 errors stemming from 20 clusters, fewer than the 30 which is considered ideal to generate reliable clustered standard errors. As suggested by Cameron, Gellbach and Miller (2008), we estimate p-values with wild bootstrap. The wild bootstrap p-values also find state ownership had no significant impact on TFP and partial productivity of labor, capital and fuel.

${ }^{22}$ These results are available upon request.
} 
insignificant as seen by the wide confidence intervals. TFP did not change significantly in the years before and after a state takeover. It hovers around zero, increasing slightly in the years up to takeover and then decreasing slightly in the years after. The long run view suggests TFP decreases up to year 6 and then begins to increase. We are cautious putting too much weight on this long run pattern because the coefficients are statistically insignificant and we observe only 6 of the 8 switching railways in the 5 to 10 year window after takeover.

Table 3 presents results on such dynamics creating bins for the three years before takeover, for the year of takeover plus the next two years, and a final bin for years 3 or more after takeover. We find no significant difference between the short run and long run effects of state ownership. For example, in the case of TFP-LP the coefficients are small and insignificant in both cases. The coefficients on the three year window before takeover are also insignificant for the most part. There is a mild anticipation effect for TFP-IN but this does not change the findings on state ownership post takeover. Broadly, these results suggest state ownership did not have differential effects in the short run and anticipation effects are not driving the findings.

There may be some concern that we are not picking up any anticipation effects because they were relevant for only a few firms. Based on the institutional history, we believe only certain firms could have anticipated state takeovers with a reasonable amount of certainty. The East Indian was the first company acquired by the Government of India in 1879 and a lot of uncertainty surrounded this takeover (Huddleston 1906). Firms such as Eastern Bengal, Sind, Punjab and Delhi, Oudh and Rohilkhand, and South Indian were in the next set of takeovers in the 1880s shortly after the East Indian. Similar to the East Indian, it was still unclear if the Government was going to takeover these companies or adopt an alternate policy. However, after these takeovers in the 1880s, the Great Indian Peninsula, Madras, and Bombay, Baroda and Central India railways were less uncertain about their future when their contracts came due in the 1900s. Recall these three railways were associated with the 1869 deal with the Secretary of State. We would expect anticipation effects to be most relevant for this group of railways because their probability of takeover was high given the Government's past behavior.

To test whether anticipation effects were indeed larger for the 'Deal of 1869' railways , we interact a dummy for these three systems with the same before and after bins as in table 3. We find no evidence of a significant differential anticipation effect for these firms in the three years before takeover (see table 4). ${ }^{23}$ Moreover, there are no differential effects

\footnotetext{
${ }^{23}$ There is weak evidence for an absolute anticipation effect for GIPR, Madras and BB\&CI railways in
} 
of state ownership on TFP for this group. There is one interesting difference between railway systems purchased in the 1870s and 1880s versus in the 1900s. In the former, capital productivity declines substantially in the first three years after takeover, but for the latter capital productivity does not decline and even shows a positive trend (albeit insignificant). It is possible that early takeovers were associated with some misallocation of capital, but there was some learning which minimized the later effects.

It is useful to point out how our estimates compare with the literature. Most privatization studies find a positive effect on firm performance following a switch to private ownership on the order of 20 percent (Gureiv and Megginson 2007). Applying these findings to a nationalization suggests state ownership should reduce firm performance by 20 percent on average. Even the lower end of the 95 percent confidence interval on our state ownership coefficients does not produce negative effects of that magnitude. Rather, state ownership in the worst case could have reduced TFP by -13 percent (TFP-IN) or -7 percent (TFP-LP). These are the low end of the 95 percent confidence interval on the estimates presented in table $2 \mathrm{~A}$. It is also interesting that our coefficient on state ownership is positive but insignificant for labor productivity contrary to the findings of many privatization studies where a change from state to private ownership improves labor productivity. For example, Ramamurti (1997) estimates that labor productivity increased by $370 \%$ following the privatization of Argentine railways in the early 1990s.

Colonial India was a British colony, not a democracy. This suggests our estimates are perhaps more comparable to studies in non-democratic settings. Given this benchmark, the findings are less surprising. For example, Brown, Earle and Telegdy (2006) find negative and insignificant effects of privatization in Russia in similar models with firm fixed effects and firm specific trends. In fact, their best case scenario suggests privatization could have increased TFP by 5.3 percent. $^{24}$ This is similar to our worst case impact of -7 percent following nationalization above. In Singapore, Feng, Sun and Tong (2004) find small and statistically insignificant differences between 30 government-linked companies and a matched sample of non government-linked companies. Surprisingly the coefficients on an indicator variable for government-linked companies are positive, though insignificant, for efficiency and leverage measures. The historical example of Indian railways combined with firms in contemporary Russia and Singapore highlight that nationalizations are not necessarily inefficient and privatizations are not necessarily efficient. The incentives of the state and

the solo panel. The sum of the dummy variables for state ownership and the interaction with deal of 1869 railways is negative and marginally significant at the 10 percent level but only in the three years prior to takeover.

${ }^{24}$ The upper end of the 95 percent confidence interval on the estimates for Russia in Table 5, FE\&FT. 
firm are critical for performance.

Contemporary China offers another comparison, a non-democratic setting where the state has introduced elements of private ownership in state-owned enterprises. The findings from these studies are mixed. Some suggest positive effects of ownership reform towards privatization of as large as 30 percent on the growth of TFP (Dong, Putterman and Unel 2006). Others find insignificant differences in productivity between private domestic and state owned firms in fixed effects models (Yusuf, Nabeshima, and Perkins 2006). The diversity of estimates is due to different methods and data sources. ${ }^{25}$ It is unsurprising then that the Indian findings generally lie within the range of estimates for China.

\subsection{Investment, Capital-Labor Ratio and Fares}

We explore the effects of state ownership on other indicators of railway operations in this sub-section. One explanation for why state ownership of Indian railways did not negatively influence productivity is that the operation of railways was similar under the two regimes. To assess this conjecture, we test whether the change to state ownership changed investment decisions, the mix of capital to labor, and average fares to passengers and freight.

Panel A in table 5 presents the results on the long run effects of state ownership for both the solo and joint panels. In the solo panel of railways, we find investment increased on average under state ownership. This increase is driven by key mergers that occurred in the years immediately following state takeovers. We find no significant effect of state ownership on investment in the joint panel, which accounts for mergers by joining the information of pre-merged lines in the years before they merge. Thus, the Government of India increased investment via mergers under state ownership, but this did not lead to greater investment in the regional railway networks that were formed. One might expect that the increase in scale that we observe in the solo panel after state takeovers contributed to higher TFP. But, it did not because we observe similar results on TFP across the solo and joint panels (see tables $2 \mathrm{~A}$ and $2 \mathrm{~B}$ ). The reason is that Indian railways did not exhibit economies of scale in this period. Our estimates of the railway production function do not reject constant returns (see Bogart and Chaudhary 2013). In unreported specifications, we tested whether there were differential effects of state ownership for railways near other companies that were state-owned. There was no evidence of such differential effects. We also found no differential effects of state ownership on density defined as train miles run divided by track mileage. ${ }^{26}$

\footnotetext{
${ }^{25}$ See the discussion in Estrin et al. 2007 for details. They indicate that few studies use panel data on switching and non-switching firms.

${ }^{26}$ Results available upon request.
} 
Specifications 3 and 4 focus on the capital-labor ratio. Here we observe a large, positive and significant effect of state ownership in both panels. Under Government ownership, capital-labor ratios increased by 10 percent in the joint panel. This effect is not driven by anticipation effects as seen in the dynamic specifications (panel B) and is not a short run phenomenon. The coefficient on state ownership 3 or more years after takeover is large and statistically significant (specification 4). We know from earlier work (Bogart and Chaudhary 2012) that labor conditional on fixed inputs (miles, locomotives and vehicles) declined under state ownership in India. These findings on the capital-labor ratio match those results.

It may come as a surprise to many readers that the growth rate of capital outpaced the growth rate of labor under Government ownership. Many privatization studies find that capital-labor ratios increase under private ownership contrary to our results here (see the review by Guriev and Megginson 2007). We think two factors account for this finding. First, government takeovers reduced or eliminated guarantees which had the effect of lowering the price of capital. Second, the Government of India represented the interests of a colonial state and was not accountable to the Indian population. Similar to private firms, the state could hire and fire labor without political repercussions at least in our period of study. This may account for why the Government chose not to increase labor relative to capital unlike recent governments that are often beholden to labor unions for political power.

Specifications 5 to 8 test the effects of ownership on average passenger and freight fares. Similar to the findings on productivity, we find no significant change in fares following the transition to state ownership. The coefficients on state ownership, especially in the joint panel, are small in magnitude and statistically insignificant. Accounting for anticipation effects or dynamics in panel B does not change the picture. The contracts with the guaranteed companies stipulated that firms could set fares only within Government approved minimum and maximum guidelines. It may well be the case that such guidelines forced companies to charge users similar to what the Government would have charged. The fares results also show that the Government of India was unwilling to push down rates and undermine profitability. Given that TFP did not increase with ownership the Government could lower fares only at the cost of profits. Given its fiscal reliance on railways, this would have been a costly decision.

\section{Conclusion}

A large literature in economics has debated the appropriate ownership structure of firms with the theoretical literature largely highlighting the negative effect of state ownership on 
productive efficiency. In this paper, we use history to examine a context where identification is more robust compared to other contexts. Our results show there was no negative effect of Government of India ownership on railway TFP, or capital and labor productivity. Government ownership increased the operating scale of railway systems and contributed to a more capital intensive operation of railways, but neither of these changes negatively influenced TFP. The results may appear surprising to some readers in view of standard models of public and private ownership. But, they are consistent with a small number of empirical studies that find limited evidence of negative effects of state ownership.

Two key features of the Indian context are important for understanding our results. First, the Government of India had strong fiscal incentives to maintain the productivity of railways and their colonial authority allowed them to enact changes similar to private companies. The Government was not encumbered by constituent demands for high employment and redundant services. Although it is certainly not a model for development, the Government's structure was not inconsistent with a productive operation of state-owned railways. A broader lesson is that the efficacy of state ownership often depends on institutions. Under some conditions state owned firms can operate like private firms and create similar incentive structures for employees.

Second, private railways in India were regulated and subsidized through guarantees. The high-powered incentives often associated with private ownership were weakened in India. Despite our historical lens, the Indian model of private ownership with subsidies is not exceptional in industries with heavy capital investment. For example, government subsidies and guarantees are common when the private sector plays a role in infrastructure provision. Foster and Yepes (2006) find that in a worldwide sample of 132 water utilities, 39 percent rely entirely on subsidies and another 30 percent only partially recover their operating or capital costs through user-fees. Foster and Briceno-Garmendia (2009) estimate that in SubSaharan Africa the electricity sector recovers 75 percent of its costs from user-fees and the water and sanitation sector recovers about 64 percent of its costs. Just two years ago, Britain agreed to a multi billion subsidy to a foreign company to construct its first nuclear power plant (Wintour 2013). ${ }^{27}$ As quoted by journalist Patrick Wintour, "The guaranteed subsidies promised by the government for Hinkley Point $\mathrm{C}$ will lead to accusations that ministers are loading a further cost on spiraling energy prices by again requiring British taxpayers to subsidize nuclear power. The coalition counters that similar subsidies are going to other carbon-free industries such as renewables and that the country needs the energy security and steady base load that nuclear provides."

\footnotetext{
${ }^{27}$ See http://www.theguardian.com/environment/2013/oct/20/nuclear-power-station-hinkley-edf
} 
In the historical railway era and today, government guarantees arise because contracts are incomplete and private firms will require some insurance against demand risk before investing. The downside is such guarantees encourage moral hazard problems and can lead to poor operational performance. In many industries, like railways, the debate is not between a theoretical public or private firm in an unregulated market, but rather between state ownership and private ownership with subsidies and regulation. In these settings, private ownership is perhaps less productive than say in manufacturing where firms are less likely to be compensated with subsidies. In conclusion, we believe the debate on the appropriate organizational form for efficiency will likely continue as theory and empirics are suggesting that private ownership with government assistance can yield better or worse performance in different informational and institutional environments.

\section{References}

1. Anuatti-Neto, Francisco, Milton Barossi-Filho, A. Gledson De Carvalho and Roberto Brás Matos Macedo. 2004. "Costs and Benefits of Privatization: Evidence from Brazil," In The Truth about Privatization in Latin America, edited by Alberto Chong and Florencio López-de-Silanes. Stanford University Press.

2. Auriol, Emmanuelle, and Pierre M. Picard. 2009. "Infrastructure and Public Utilities Privatization in Developing Countries." World Bank Economic Review, 23(1): 77-100.

3. Bell, Horace. 1894. Railway Policy of India: With Map of Indian Railway System. Irvington: Percival.

4. Besley, Tim and Maitreesh Ghatak. 2001. "Government versus Private Ownership of Public Goods," Quarterly Journal of Economics, 116 (4): 1343-1372.

5. Bogart, Dan. 2010. "A Global Perspective on Railway Inefficiency and the Rise of State Ownership, 1880-1912." Explorations in Economic History, 47 (2): 158-178.

6. Bogart, Dan and Latika Chaudhary. 2012. "Regulation, Costs, and Ownership: A Historical Perspective from Indian Railways," American Economic Journal: Economic Policy, 4 (1): 28-57.

7. Bogart, Dan and Latika Chaudhary. 2013. "Engines of Growth: The Productivity Advance of Indian Railways," Journal of Economic History, 73 (2): 340-371. 
8. Boycko, Maxim; Andrei Shleifer, and Robert W. Vishny. 1996. "A Theory of Privatization," Economic Journal, 106: 309-19.

9. Brown, J. David, John S. Earle, and Almos Telegdy. 2006. "The Productivity Effects of Privatization: Longitudinal Estimates from Hungary, Romania, Russia, and Ukraine," Journal of Political Economy, 114 (1): 61-99.

10. Cameron, A. Colin, Jonah B. Gellbach, and Douglas L. Miller. 2008. "BootstrapBased Improvements for Inference with Clustered Errors," Review of Economics and Statistics, 90 (3): 414-427.

11. Caves, Douglas W. and Laurits R. Christensen. 1980. "The Relative Efficiency of Public and Private Firms in a Competitive Environment: The Case of Canadian Railroads," Journal of Political Economy, 88 (5):958-976.

12. Claessens, Stijn, and Simeon Djankov. 2002. "Privatization Benefits in Eastern Europe." Journal of Public Economics, 83(3): 307-24.

13. Crafts, Nicholas, Terence C. Mills, Abay Mulatu. 2007. "Total factor productivity growth on Britain's railways, 1852-1912: A reappraisal of the evidence." Explorations in Economic History, 44 (4): 608-634.

14. Derbyshire, Ian. 1987. "Economic Change and the Railways in Northern India, 18601914." Modern Asian Studies, 21 (3): 521-545.

15. Djankov, Simeon, and Peter Murrell. 2002. "Enterprise Restructuring in Transition: A Quantitative Survey." Journal of Economic Literature, 40(3): 739-92.

16. Dong, Xiao-yuan, Louis Putterman, and Bulent Unel. 2006. "Privatization and Firm Performance: A Comparison between Rural and Urban Enterprises in China." Journal of Comparative Economics, 34(3): 608-33.

17. Eichengreen, Barry. 1995. "Financing Infrastructure in Developing Countries: Lessons from the Railway Age." World Bank Research Observer, World Bank Group, vol. 10(1), pages 75-91, February.

18. Engel, Eduardo, Ronald Fischer and Alexander Galetovic. Forthcoming. "The Basic Public Finance of Public-Private Partnerships." Journal of the European Economic Association. 
19. Engel, Eduardo, Ronald Fischer and Alexander Galetovic. 2009. "On the Efficient Provision of Roads." http://cowles.econ.yale.edu/ engel/pubs/efg_efficient-prov.pdf.

20. Estache, Antonio, and Liam Wren-Lewis. 2009. "Toward a Theory of Regulation for Developing Countries: Following Jean-Jacques Laffont's Lead." Journal of Economic Literature, 47(3): 729-70.

21. Estache, A., González, M., \& Trujillo, L. 2002. "What does "privatization" do for efficiency? Evidence from Argentina's and Brazil's railways." World Development, 30(11): 1885-1897.

22. Estache, A., Perelman, S., \& Trujillo, L. 2006. "Infrastructure Reform in Developing Economies: Evidence from a Survey of Economic Performance Measures." Peformance Measurement and Regulation of Network Utilities, 133-74.

23. Estache, Antonio (2010). Infrastructure Finance in Developing Countries: An Overview, EIB Papers, European Investment Bank, Economics Department.

24. Estrin, Saul, Jan Hanousek, Evžen Kočenda and Jan Svejnar. 2009. "The Effects of Privatization and Ownership in Transition Economies. Journal of Economic Literature, 47 (3): 699-728.

25. Fang Feng, Qian Sun, Wilson H.S. Tong. 2004. "Do government-linked companies underperform?" Journal of Banking \& Finance, 28 (10): 2461-2492

26. Fishlow, Albert. 1966. "Productivity and Technological Change in the Railroad Sector, 1840-1910" in Output, Employment, and Productivity in the United States after 1800. Ed. Dorothy S. Brady. New York: National Bureau of Economic Research.

27. Foster, V. and Briceno-Garmendia, C. (eds.) 2009. Africa Infrastructure Country Diagnostic, The World Bank, Washington, D.C.

28. Foster, V. and Yepes, T. 2006. "Is Cost Recovery a Feasible Objective for Water and Electricity? The Latin American Experience". Policy Research Working Paper No. 3943, The World Bank.

29. Galiani, Sebastián, Paul Gertler, Ernesto Schargrodsky and Federico Sturzenegger. 2004. "The Benefits and Costs of Privatization in Argentina: A Microeconomic Analysis," In The Truth about Privatization in Latin America, edited by Alberto Chong and Florencio López-de-Silanes. Stanford Unviersity Press. 
30. Government of India. 1882-1912. Administration Report on the Railways in India. Calcutta: Superintendent Government Printing.

31. Government of India. 1860-1881. Report to the Secretary of State for India in Council on Railways in India. Calcutta: Superintendent Government Printing.

32. Government of India. 1955. History of Indian Railways Constructed and In Progress; Corrected up to 31 March 1955. Delhi: Ministry of Railways (Railway Board).

33. Great Britain. 1878. Statistical abstract relating to British India from $1867 / 8$ to 1876/\%. London: Her Majesty's Stationary Office.

34. Great Britain, 1922. Statistical abstract relating to British India from 1910-11 to 1919-20. London: His Majesty's Stationary Office 1922.

35. Guriev, Sergei and William L. Megginson. 2007 "Privatization: What Have We Learned?" In Bourguignon, Francois, and Pleskovic, Boris, ed. Beyond Transition. Proceedings of the 18th ABCDE, World Bank.

36. Hart, Oliver, Andrei Shleifer, and Robert Vishny. 1997. "The Proper Scope of Government: Theory and an Application to Prisons," Quarterly Journal of Economics, 112 (4): 1119-1158.

37. Huddleston, George. 1906. History of the East Indian Railway, Volume 1. Calcutta: Thacker, Spink, and Co.

38. Hurd, John and Ian J. Kerr. 2012. India's Railway History: A Research Handbook. Brill Academic Publishers, Inc.

39. Hurd, John. 1983. "Railways" in The Cambridge Economic History of India, vol. 2. London: Cambridge University Press.

40. Jones, Derek C., and Niels Mygind. 2002. "Ownership and Productive Efficiency: Evidence from Estonia," Review of Development Economics, 6(2): 284-301.

41. Kerr, Ian. 1983. "Constructing railways in India-an estimate of the numbers employed, 1850-80. Indian Economic and Social History Review, 20 (3): 317-341.

42. Kerr, Ian. 2007. Engines of Change: The Railroads that Made India. Westport: Praeger. 
43. Kole, Stacey R. and J. Harold Mulherin. 1997. "The Government as a Shareholder: A Case From the United States," Journal of Law and Economics 40 (1):1-22.

44. Kornai, János, Eric Maskin, and Gerard Roland. 2003. "Understanding the Soft Budget Constraint." Journal of Economic Literature, 41(4): 1095-1136.

45. Laurin, Claude, and Yves Bozec. 2001. "Privatization and Productivity Improvement: The Case of the Canadian National," Transportation Research Part E: Logistics and Transportation Review, 37(5): 355-74.

46. Levinsohn, James and Amil Petrin. 2003. "Estimating Production Functions using Inputs to Control for Unobservables. Review of Economic Studies, 70 (2): 317-342.

47. La Porta, Rafael, and Florencio Lopez-de-Silanes. 1999. "The Benefits of Privatization: Evidence from Mexico," Quarterly Journal of Economics, 114(4): 1193-1242.

48. Li, Wei. 1997. "The Impact of Economic Reform on the Performance of Chinese State Enterprises, 1980-1989," Journal of Political Economy, 105 (5):1080-1106.

49. Marshall, Alfred. 2006. Industry and Trade (Vol. 2). Cosimo, Inc..

50. Martimort, D. 2006. "An Agency Perspective on the Costs and Benefits of Privatization," Journal of Regulatory Economics, 30: 5-44.

51. Megginson, William, Robert Nash and Matthias van Randenborgh. 1994. "The Financial and Operating Performance of Newly Privatized Firms: An International Empirical Analysis." Journal of Finance 49: 403-452.

52. Megginson, William L. and Jeffry M. Netter. 2001. "From State to Market: A Survey of Empirical Studies on Privatization." Journal of Economic Literature, 39 (2):321389.

53. Ramamurti, Ravi. 1997. "Testing the Limits of Privatization: Argentine Railroads," World Development, 25: 1973-93.

54. Roberston, Thomas. 1903. Report on the Administration and Working of Indian Railways. London: Darling \& Son.

55. Roy, Tirthankar. 2011. The Economic History of India 185\%-194\%. New Delhi: Oxford University Press. 
56. Sanyal, Nalinksha. 1930. Development of Indian Railways. Calcutta: University of Calcutta.

57. Sappington, David E.M. and Joseph E. Stiglitz. 1987. "Privatization, Information and Incentives," Journal of Policy Analysis and Management, 6 : 567-82.

58. Shleifer, Andrei. 1998. "State versus Private Ownership," Journal of Economic Perspectives, 12 (4): 133-150.

59. Shirley, Mary M., and Patrick Walsh. 2000. "Public versus Private Ownership: The Current State of the Debate," World Bank Policy Research Working Paper 2420.

60. Sun Qian and Wilson H.S. Tong. 2003. "China's Share Issue Privatization: The Extent of its Success," Journal of Financial Economics, 70:183-222.

61. Sweeney, Stuart. 2011. Financing India's Imperial Railways, 1875-1914. London: Pickering.

62. Syverson, Chad. 2011. "What Determines Productivity?," Journal of Economic Literature, 49 (2): 326-65.

63. Thorner, Daniel. 1977. Investment in Empire: British Railways and Steam Shipping Enterprise in India 1825-1949. Philadelphia: University of Pennsylvania Press.

64. Van Biesebroeck, Johannes. 2008. "The Sensitivity of Productivity Estimates: Revisiting Three Important Debates." Journal of Business and Economic Statistics, 26 (3): 311-328.

65. Villalonga, Belen. 2000. "Privatization and Efficiency: Differentiating Ownership Effects from Political, Organizational and Dynamic Effects," Journal of Economic Behavior and Organization, 42: 43-74. 
Figure 1: Map of India, 1870

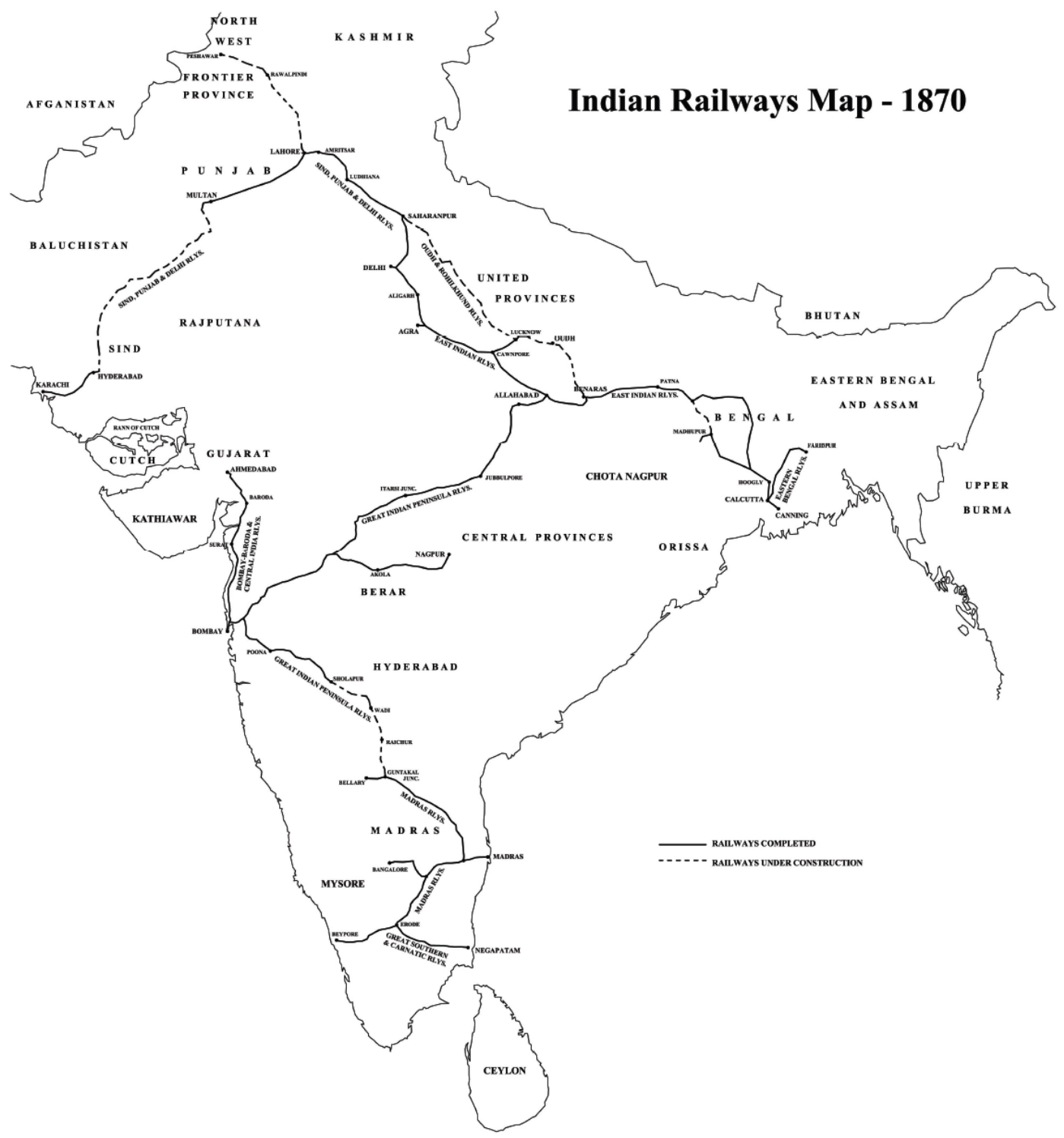


Figure 2: TFP Industry Index, 1874-1912 (1874=100)

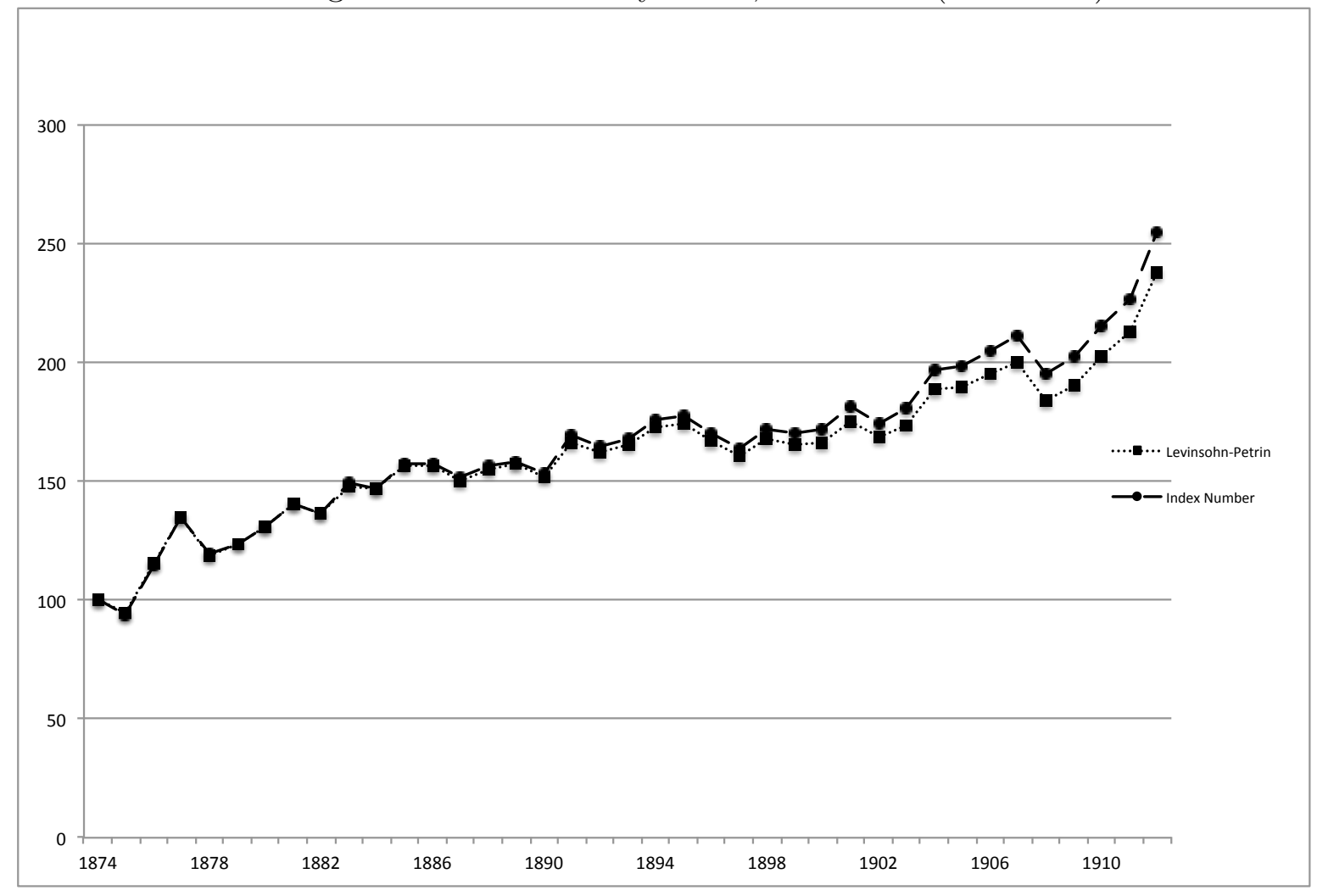


Figure 3: Mileage by Ownership, 1874-1912

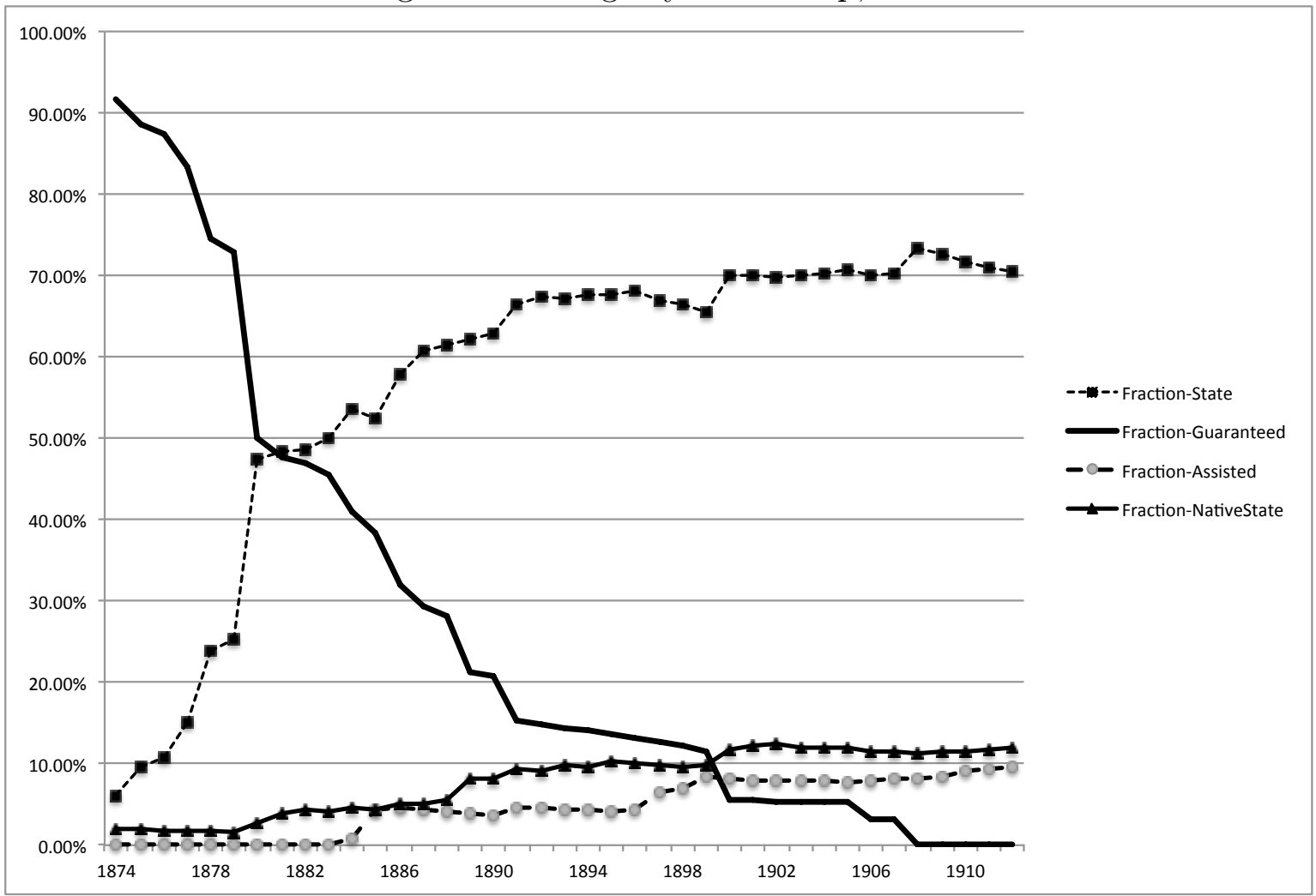


Figure 4: Dynamics of TFP-LP for Switchers 3 years Pre and 10 years Post Takeover

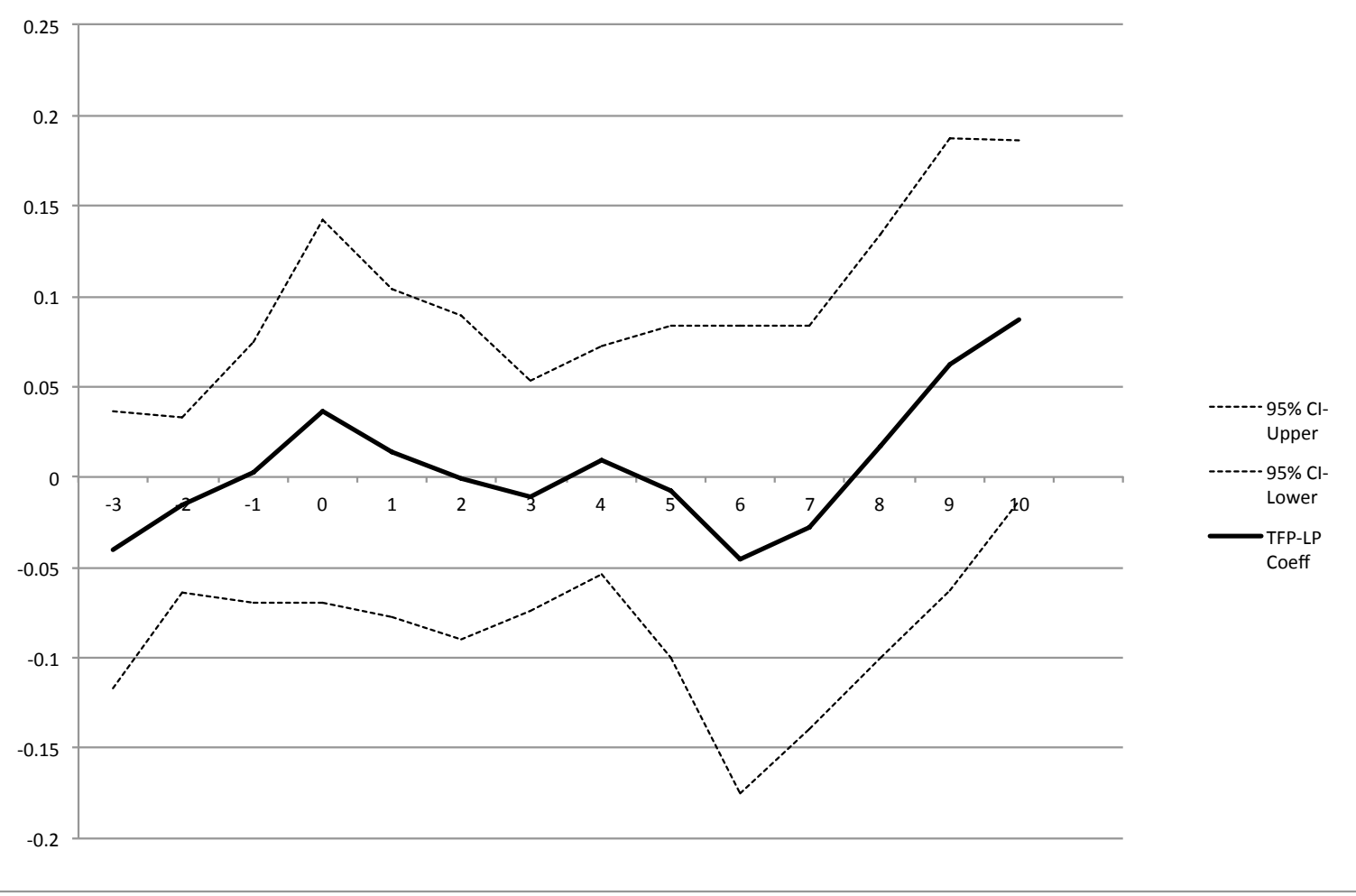


Table 1A: Summary Statistics (Joint Panel 1874-1912)

\begin{tabular}{lccccc}
\hline \hline Variable & Obs & Mean & Std. Dev & Min & Max \\
\hline & & & & & \\
(logs) & 637 & 4.49 & 0.35 & 3.10 & 5.36 \\
TFP (IN) & 637 & 8.35 & 0.24 & 6.87 & 9.07 \\
TFP (LP) & 637 & 9.66 & 0.40 & 7.41 & 10.64 \\
Labor Prod. & 637 & 0.64 & 0.43 & -1.44 & 1.60 \\
Capital Prod. & 637 & 8.29 & 0.26 & 6.77 & 9.30 \\
Fuel Prod. & 637 & 9.02 & 0.32 & 7.63 & 10.61 \\
Capital/Labor & & & & & \\
& 619 & 5.71 & 10.67 & -36.83 & 137.45 \\
Investment per 1M Rupees & 545 & 2.51 & 0.45 & 1.54 & 8.07 \\
Avg. Passenger Fare (pies) & 545 & 7.30 & 2.44 & 3.08 & 20.17 \\
Avg. Freight Fare (pies) & 540 & & & \\
& 637 & $71.74 \%$ & $45.06 \%$ & $0.00 \%$ & $100.00 \%$ \\
State Ownership & 637 & $50.57 \%$ & $42.92 \%$ & $0.00 \%$ & $100.00 \%$ \\
Fraction State Ownership & & & & & \\
& & & & &
\end{tabular}

Source: See text for details.

The fare data are reported only from 1880-1912. 
Table 1B: Summary Statistics for Switching and Non-Switching Railways (Joint Panel)

\begin{tabular}{|c|c|c|c|c|c|}
\hline \multicolumn{6}{|c|}{ Panel A: Entire Time Period 1874-1912 } \\
\hline & \multicolumn{2}{|c|}{ Non-Switching } & \multicolumn{2}{|c|}{ Switching } & \multirow[t]{2}{*}{ Diff } \\
\hline & Mean & Std. Dev & Mean & Std. Dev & \\
\hline \multicolumn{6}{|l|}{$(\log s)$} \\
\hline TFP (IN) & 4.46 & 0.40 & 4.53 & 0.29 & $-0.0644^{*}$ \\
\hline TFP (LP) & 8.35 & 0.27 & 8.34 & 0.20 & 0.01 \\
\hline Labor Prod. & 9.55 & 0.45 & 9.76 & 0.32 & $-0.208^{* * *}$ \\
\hline Capital Prod. & 0.63 & 0.49 & 0.65 & 0.36 & -0.0135 \\
\hline Fuel Prod. & 8.31 & 0.30 & 8.28 & 0.21 & 0.0369 \\
\hline Capital-Labor Ratio & 8.92 & 0.34 & 9.12 & 0.26 & $-0.195 * * *$ \\
\hline Investment per $1 \mathrm{M}$ Rupees & 4.13 & 7.35 & 7.27 & 13.06 & $-3.136^{* * *}$ \\
\hline Observation & \multicolumn{2}{|r|}{332} & \multicolumn{2}{|r|}{312} & \\
\hline \multicolumn{6}{|c|}{ Panel B: Pre-Treatment Period Only } \\
\hline & \multicolumn{2}{|c|}{ Non-Switching } & \multicolumn{2}{|c|}{ Switching } & Diff \\
\hline & Mean & Std. Dev & Mean & Std. Dev & \\
\hline \multicolumn{6}{|l|}{$(\operatorname{logs})$} \\
\hline TFP (IN) & 4.32 & 0.44 & 4.37 & 0.27 & -0.0494 \\
\hline TFP (LP) & 8.34 & 0.35 & 8.31 & 0.21 & 0.0238 \\
\hline Labor Prod. & 9.34 & 0.52 & 9.63 & 0.33 & $-0.294^{* * *}$ \\
\hline Capital Prod. & 0.49 & 0.50 & 0.44 & 0.33 & 0.0512 \\
\hline Fuel Prod. & 8.33 & 0.36 & 8.26 & 0.21 & $0.0710^{*}$ \\
\hline Capital-Labor Ratio & 8.85 & 0.36 & 9.19 & 0.29 & $-0.345^{* * *}$ \\
\hline Investment per 1M Rupees & 3.96 & 6.94 & 4.22 & 11.37 & -0.266 \\
\hline Observation & \multicolumn{2}{|r|}{149} & \multicolumn{2}{|r|}{152} & \\
\hline
\end{tabular}

Source: See text for details. Differences are statistically significant at $* \mathrm{p}<0.05$, ** $\mathrm{p}<0.01,{ }^{* * *} \mathrm{p}<0.001$. To calculate the pre-treatment mean for non-switching railways, we assign 1896 as the switching year, which is the mean takeover year among the switching railways. 


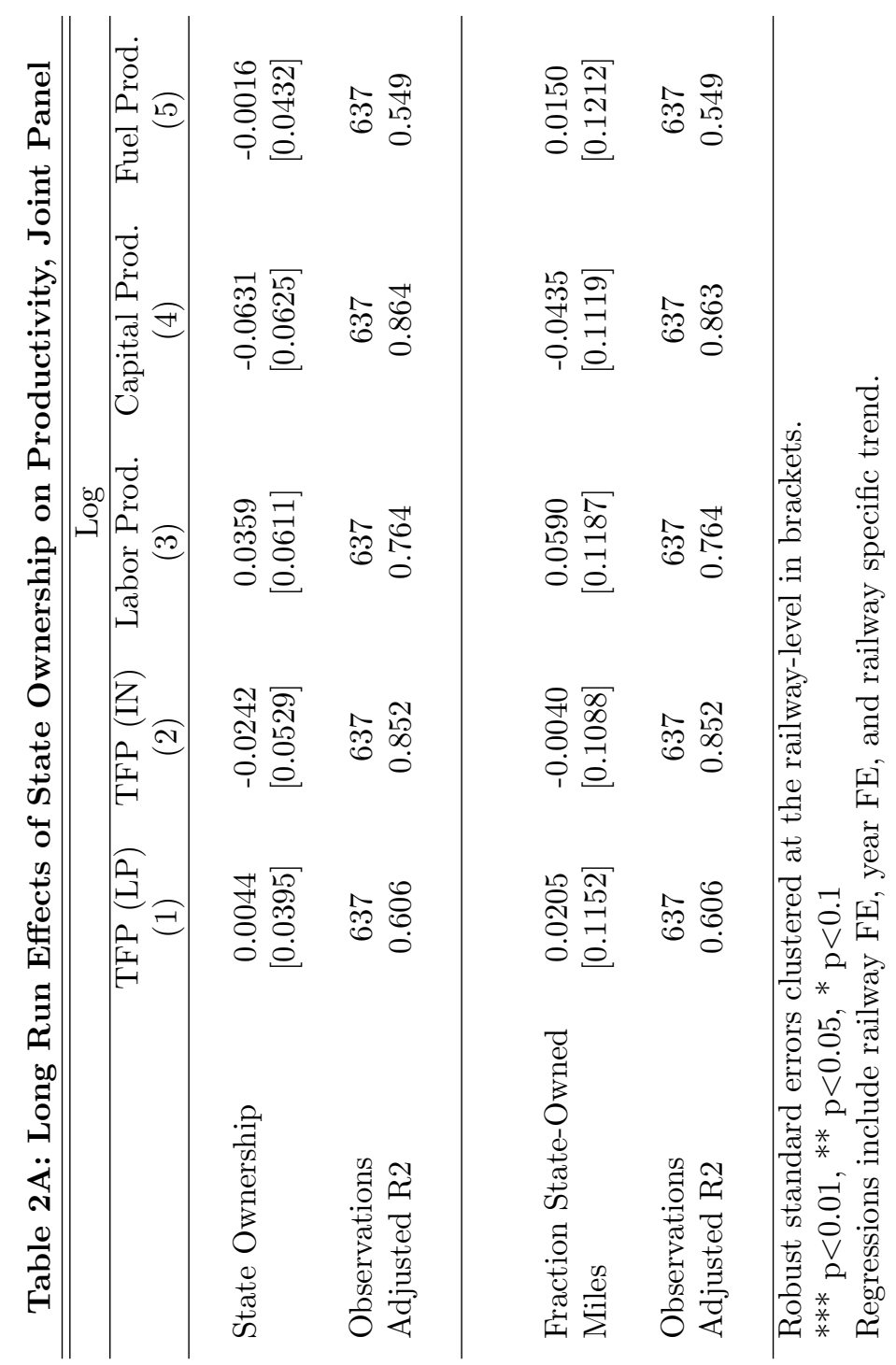




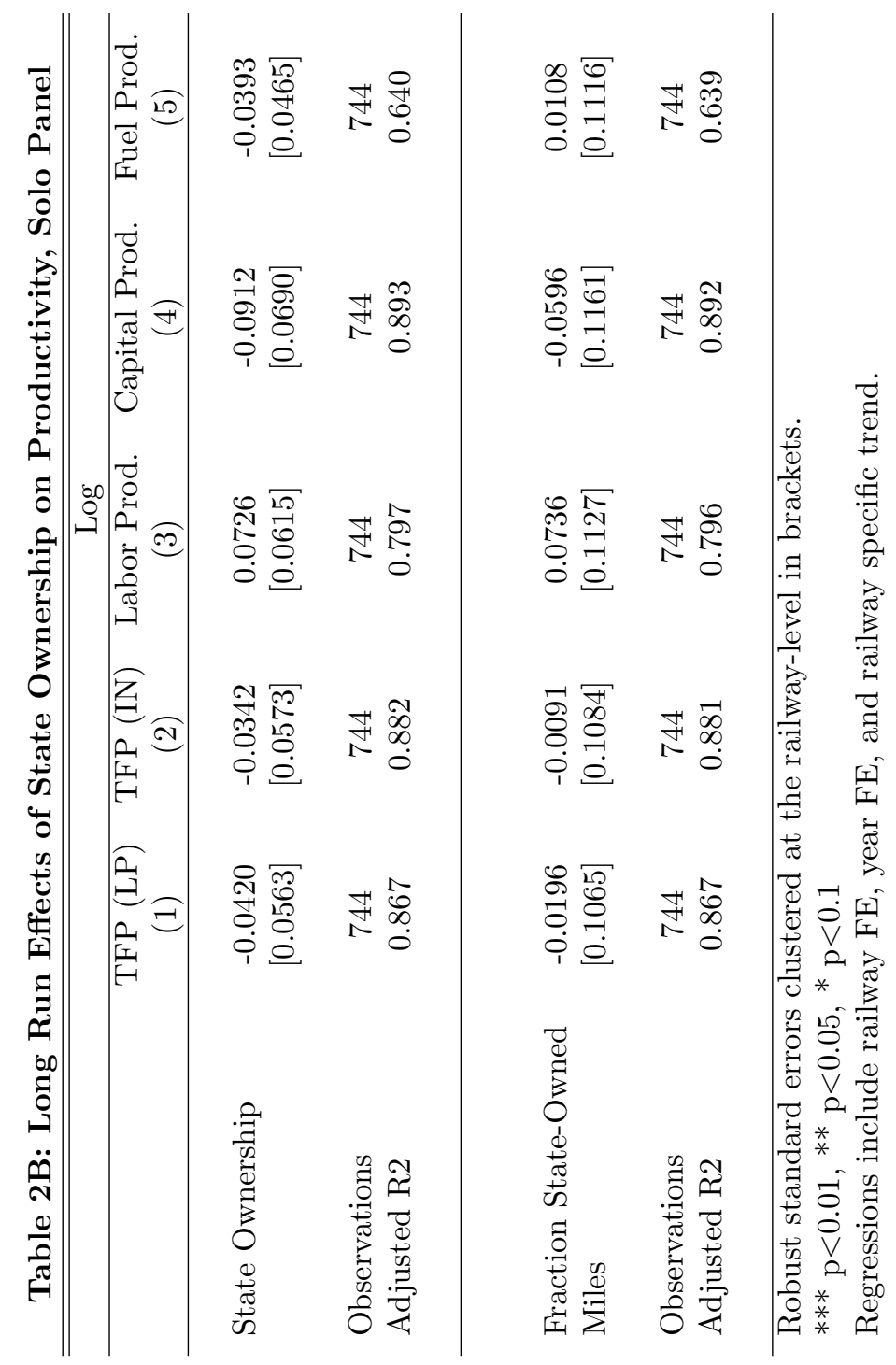




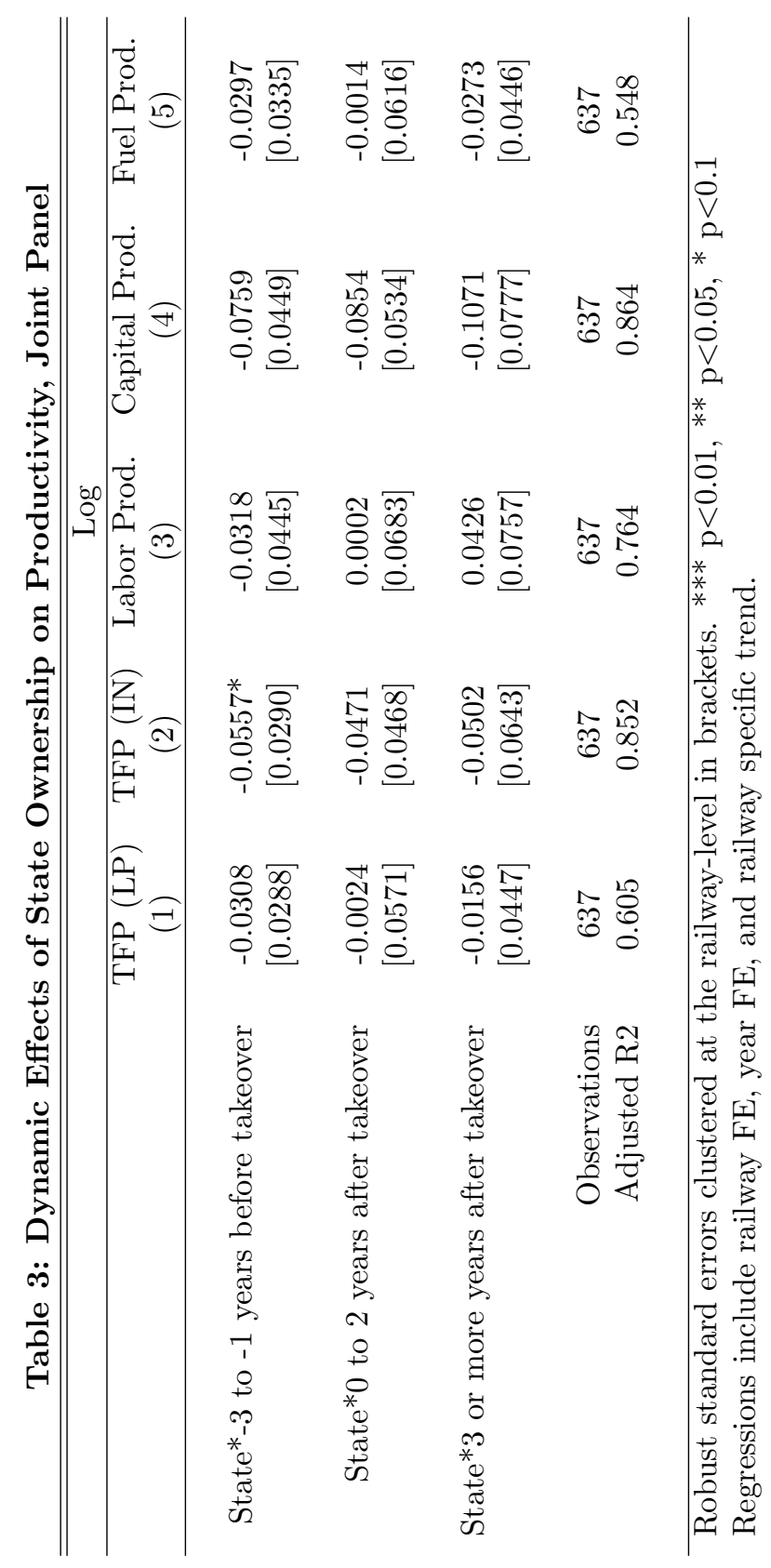




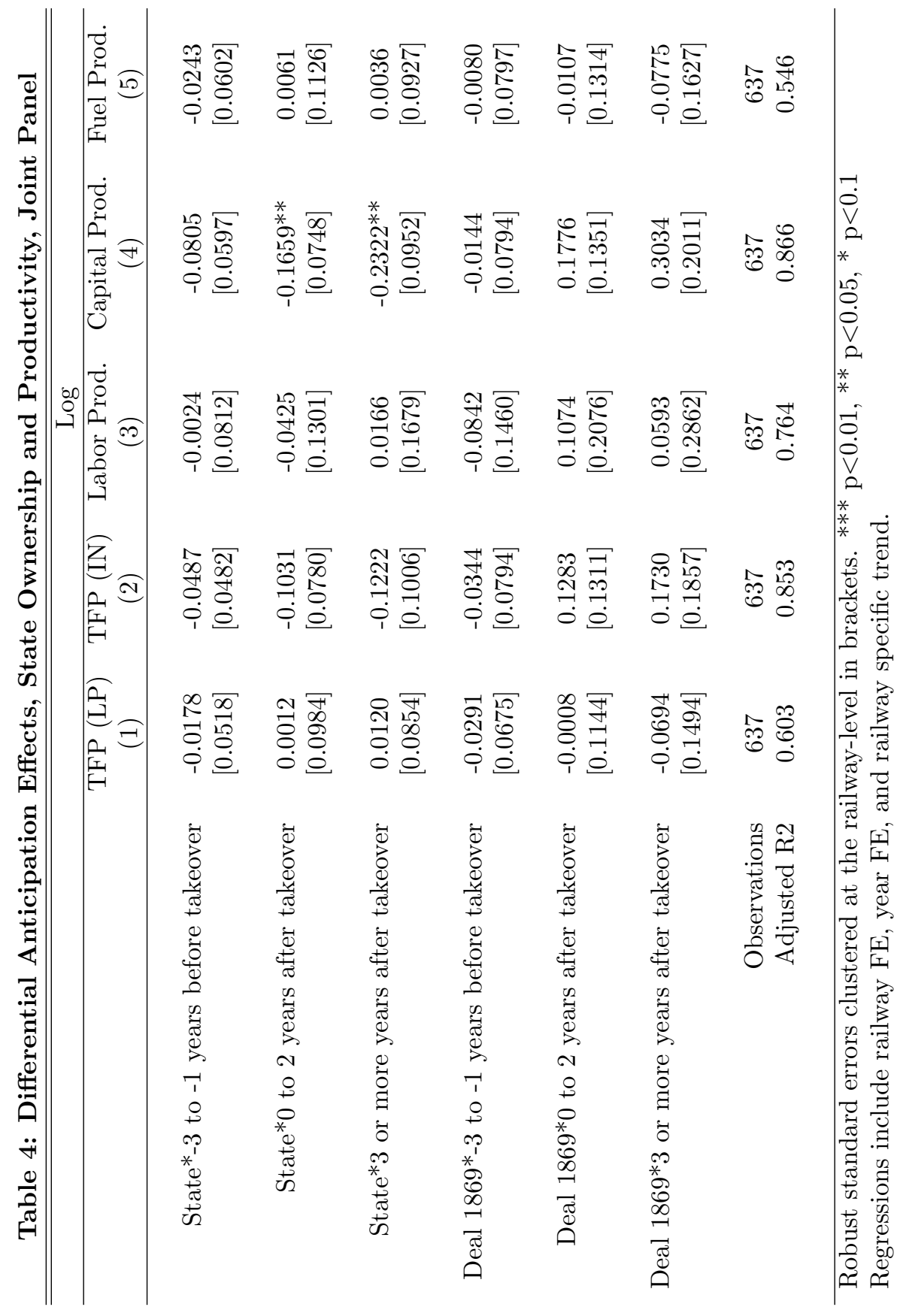




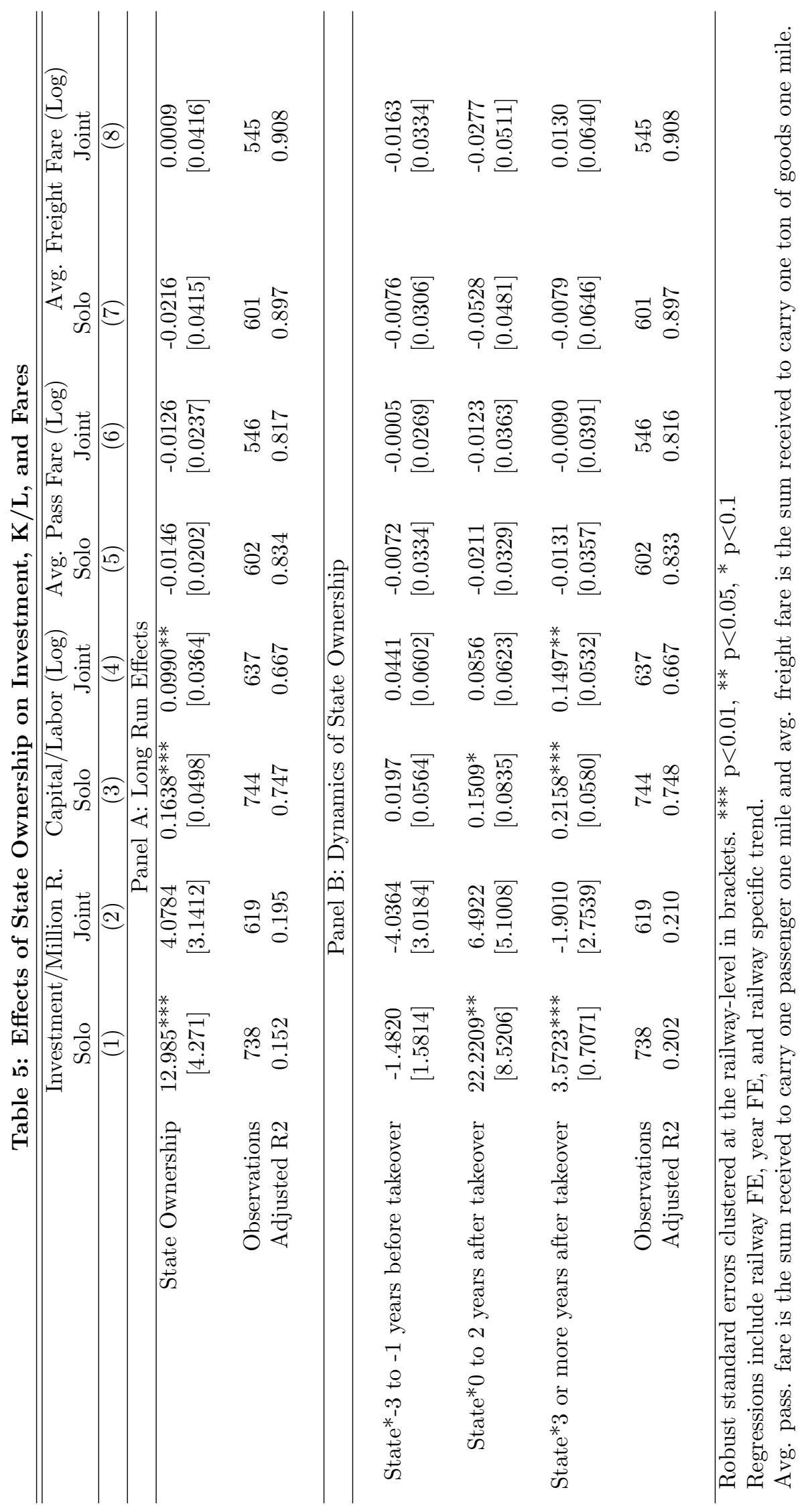

